\title{
MODELAGEM ACÚSTICA POR DIFERENÇAS FINITAS E ELEMENTOS FINITOS EM 2-D E 2,5-D
}

\author{
Francisco de Assis Silva Neto \\ Orientador: Dr. Jessé Carvalho Costa (UFPA) \\ 103 p. - Dissertação (Mestrado) - Defesa 26.01.2005
}

\begin{abstract}
RESUMO. A modelagem acústica fornece dados úteis para avaliação de metodologias de processamento e imageamento sísmico, em modelos com estrutura geológica complexa. Esquemas de diferenças finitas (DF) e elementos finitos (EF) foram implementados e avaliados em modelos homogêneos e heterogêneos. 0 algoritmo de diferenças finitas foi estendido para o caso 2,5-D em modelos com densidade variável. Foi apresentada a modelagem de alvos geológicos de interesse exploratório existentes na Bacia Paleozóica do Solimões na Amazônia. Reflexões múltiplas de longo período produzidas entre a superfície livre e a discordância Cretáceo-Paleozóica, a baixa resolução da onda sísmica nas proximidades do reservatório e as fracas reflexões na interface entre as rochas reservatório e as rochas selantes são as principais características dos dados sintéticos obtidos, os quais representam um grande desafio ao imageamento sísmico.
\end{abstract}

ABSTRACT. Acoustic modeling provides useful synthetic data for evaluating seismic processing and imaging in complex geological settings. High order finite difference(FD) and finite elements(FE) was implemented and evaluated in homogeneous and inhomogeneous model. The FD algorithm are extended to 2,5-D for variable density models. Seismic modeling of oil reservoirs targets somewhat similar to those occurring at Paleozoic Basins in the Amazon are presented. Long period multiples produced between the free-surface and the Cretaceous-Paleozoic interface, the low resolution of the seismic waves near the reservoir and the week reflections at the interface between the reservoir rocks and the cap rock are the main features of the synthetics which presents a challenge to seismic imaging. 